\title{
Development of Maize Stalk Cellulose Fiber Reinforced Calcined Kaolinite Clay Geopolymer Composite
}

\author{
Addisu Workiye ${ }^{1, *}$, Eyassu Woldsenbet ${ }^{2}$ \\ ${ }^{1}$ School of Mechanical and Industrial Engineering, Addis Ababa Institute of Technology, Addis Ababa, Ethiopia \\ ${ }^{2}$ Addis Ababa Institute of Technology, Addis Ababa University, Addis Ababa, Ethiopia \\ Received 21 July 2019; received in revised form 02 November 2019; accepted 14 January 2020 \\ DOI: https://doi.org/10.46604/peti.2020.4599
}

\begin{abstract}
In recent years the popularity of ecological and renewable materials has grown. Aware of the availability of local resources and economic grounds, the attention is paid to the development geopolymer composite. Geopolymers are inorganic polymers that are formed by the polymerization reaction of silico-aluminate and silico-oxide. The aim of the research was to develop single maize stalk cellulose fiber reinforced calcined kaolinte caly based geopolymer composite. Kaolinite clay was characterized for its chemical composition from two different sites located in Ethiopia to use as precursor material. In addition to that, single maize stalk fiber was extracted from the maize stalk local variety by using a retting process, sodium hydroxide purity $98 \%$ used for chemical treatment of the fiber for 30 minutes and its tensile strength $1184 \mathrm{Mpa}$ and young modulus 16 Gpa were determined based on AST M D3822 to use as reinforcement. Sodium hydroxide and sodium silicate in appropriate ratio were used as an alkaline activator. Therefore, the geopolymer composite developed from chemical treated short single maize stalk cellulose fiber and calcined kaolinite clay based geopolymer matrix activated by sodium water glass. Geopolymer composites reinforced with 0 weight $\%, 0.1$ weight $\%, 0.2$ weight $\%, 0.6$ weight $\%$, and 1 weight $\%$ maize stalk single cellulose were prepared and tested for compression strength according to AST M C 1424. Measured compression strength ranged from $16 \mathrm{Mpa}$ up to $27 \mathrm{Mpa}$. The result shows that the appropriate addition of single maize stalk cellulose fibers can improve the Compression strength of a calcined kaolinite based geopolymer
\end{abstract}

Keywords: geopolymer, maize, fiber, kaolin, composite

\section{Introduction}

The agricultural residue becomes a major source of fibers in the development of the building and packaging industries. Nature has given immense sources of natural fibers to humankind, especially for plant fibers, cellulose, and vegetable fibers are the main sources in the building and packaging. Natural fibers possess a lot of advantages over synthetic fibers in terms of cost, density, bio-degrading, good acoustic, mechanical properties, abundance, renewable, ease of separation, and carbon dioxide sequestration. Unlike synthetic fibers, natural fibers are flexible and less likely to be fractured during composite processing. This enables the fibers to maintain the appropriate aspect ratios to provide good composite reinforcements [1].

Maize is the global leading cereal in terms of production with 1,016 million metric tons produced on 184 million hectares globally based on the Food and Agriculture Corporate Statistical database 2013. The increasing demand for maize and its global advance implies that by 2023 the maize will account for the greatest share $(34 \%)$ of the total crop area harvested

* Corresponding author. E-mail address: natanium27@gmail.com

Tel.: +251-11-232414 
according to the Organization for Economic co-operation and Development and the Food and Agriculture Organization of the United Nations. Corn stalks consist of a pithy core with an outer layer of long fibers. Currently, the Corn stalks are chopped and used for forage, left on the field, or baled for animal bedding [2]. Maize husk and stalk were assessed for their fiber characteristics and suitability for pulp and paper production. Corn stover typically consists of about $50 \%$ stalk, $23 \%$ leaves, 15 $\%$ cobs, and $14 \%$ husk. The stalks contain an inner pith and outer rind which is the source for fibers [3]. Tensile properties measurement of the stalk rind was carried out experimentally, the rind specimens were subjected to uniaxial tensile loading at a slow rate of $3 \mathrm{~mm} / \mathrm{min}$. From the recorded load elongation curves tensile stresses and modulus of elasticity were determined [4].

The Alkaline treatment removed the lignin, cellulose, hemicellulose, and residues of the fiber's surface. Maize fibers are treated with $15 \%$ diluted sodium hydroxide solutions at room temperature for 72 hours, then the fibers were washed several times with the distilled water to remove the excess sodium hydroxide from its surface. Next, the fibers neutralized with $2.5 \%$ diluted hydrochloric [5]. Natural cellulose fibers are extracted from lignocellulose byproducts using bacteria, fungi, mechanical, and chemical methods [6]. Retting, the traditional process to extract fibers, uses bacteria and fungi in the environment to remove lignin, pectin, and other substances [7]. However, sodium hydroxide is the most commonly used chemical for fiber extraction [7]. The chemical concentration, temperature, and duration of treatment are the main factors for determining the quality of chemically extracted fibers [8].

The fundamental physical and mechanical properties of the maize fibers could be summarized as follows: a density of 1.5 $\mathrm{g} / \mathrm{cm}^{3}$, an average diameter of $145 \mu \mathrm{m}$ with a range of 60-220 $\mu \mathrm{m}$, average tensile strength, the elastic modulus of $141 \mathrm{Mpa}$, and 6.3 Gpa, respectively [9]. Also, the maize stalk fibers were tested for tensile strength; the fibers of uniform size were selected and tested in the Hounsfield tensiometer machine. The ultimate strength of the fibers was 152 Mpa with an average Young's modulus of $8582 \mathrm{Mpa}$ [10]. In many practical situations, the cross-section is assumed to be circular for natural fibers and the projected width of the fiber is used to calculate a cross-sectional area.

Kaolinite is a white hydrated aluminum silicate crystalline mineral. It is a soft powder that has a fine particle and plate-like in appearance. Large volumes of kaolin clays are used for the production of cement, ceramics, bricks, and porcelain [11]; the greatest demand for kaolinite is in the paper industry to produce a high-quality paper. It is also used as a filler for paint, rubber, and plastics [12]. The rough geology of clay is a sedimentary material with grains smaller than 0.002 millimeters in diameter [13]. The clay is in its most reactive state when the calcining temperature leads to lose hydroxides and results in a collapsed and disarranged structure [14].

The clay used for the study was calcined at a temperature ranging from $550{ }^{\circ} \mathrm{C}$ to $1100{ }^{\circ} \mathrm{C}$ and was characterized by $\mathrm{X}$-ray diffraction, infrared spectroscopy, and thermal analysis. After the clay was calcined, the clay was activated by sodium hydroxide and potassium hydroxide solutions at concentrations of 5, 8, 10, 13, 15, or $18 \mathrm{M}$. The compression strength and the water absorption of the hardened geopolymer cement paste samples were determined after 28 days [15]. Geopolymers are produced from the reaction of solid alumino-silicate precursors with the alkaline solution at room or elevated temperature. Geopolymeric cement is a new type of calcium oxide free inorganic alumino-silicate material, which has received a great deal of attention across the world in recent years [16].

The abaca fiber reinforced the foamed fly ash geopolymer. The measured compression and flexural strength ranged from 19.56 Mpa to 36.84 Mpa and 2.41 Mpa to 6.25 Mpa, respectively. The results suggest an enhancement of the compression strength by the abaca reinforcement and elevated temperature curing [17]. The use of long sisal fibers improved the mechanical properties of the composites, increasing the modulus of rupture compared to the non-reinforced matrix. Unreacted products were found in the matrices with a higher amount of activator and/or shorter curing times, demonstrating that, it may influence the final mechanical strength value [18]. A novel bio-composite panel made with recycled wood chips was presented and 
assessed. The bio-composite binder was a natural hydrated lime with the addition of metakaolin [19]. Another researcher attempted to improve brittle behavior by reinforcing the geopolymer matrix with bagasse cellulose fibers [20].

The study investigates the development of the calcined kaolin geopolymer based on composites reinforced by maize stalk fiber up to 1 weight $\%$. Maize stalk fibers are extracted by retting process and the sodium hydroxide chemical treatment done in order to enhance its hydrophobic property. Moreover, the characterization of maize stalk single fibers was conducted to the calcined kaolin based on the geopolymer composite reinforced by maize stalk fiber which was developed and its compression strength and bulk density characterized.

\section{Material and Method}

\subsection{Kaolin deposit}

In this study, the raw materials are planned to be explored from two different sites. One site is Ketchene that were found in the Gulele Sub-city of Addis Ababa where pottery making is a dominant practice in this area. The other site is Burayu town, where most of the brick factories around Addis Ababa were found.

\subsection{Characterization}

Table 1 shows that the laboratory test results on the sampled soils. The chemical or oxide compositions of the four sampled soils are tested in the Ethiopian Geological Survey Laboratory. The result indicates the availability of enough $\mathrm{SiO}_{2}$ and $\mathrm{Al}_{2} \mathrm{O}_{3}$ are used as a precursor for geopolymer. From the chemical composition analysis result, chefe red clay soil were selected the material for the preparation of geopolymer paste since it has more $\mathrm{SiO}_{2}$ and $\mathrm{Al}_{2} \mathrm{O}_{3}$. The calcination process in kaolin modification enhanced the properties of the final material obtained. The calcination of kaolin removed the crystalline bound water of hydration which is usually $14 \%$ by weight. The calcined kaolin can serve as a binding agent, filler, fixing agent, heat transfer agent, catalyst support, and processing aid in a broad range of applications.

Table 1 Chemical composition of clay soil samples (\%)

\begin{tabular}{|c|c|c|c|c|c|c|c|c|c|c|}
\hline Soils Type & $\mathrm{SiO}_{2}$ & $\mathrm{Al}_{2} \mathrm{O}_{3}$ & $\mathrm{Fe}_{2} \mathrm{O}_{3}$ & $\mathrm{CaO}$ & $\mathrm{MgO}$ & $\mathrm{Na}_{2} \mathrm{O}$ & $\mathrm{K}_{2} \mathrm{O}$ & $\mathrm{TiO}_{2}$ & $\mathrm{MnO}_{2}$ & $\mathrm{P}_{2} \mathrm{O}_{5}$ \\
\hline Burayu-White clay soil one & 66.76 & 17.86 & 9.53 & 0.40 & 0.84 & 0.22 & 0.84 & 0.53 & 0.08 & 0.04 \\
\hline Burayu-White clay two & 67.55 & 13.66 & 9.62 & 0.32 & 0.73 & 2.59 & 2.56 & 0.47 & 0.26 & 0.03 \\
\hline Chefe red clay soil & 48.72 & 32.10 & 12.03 & 0.30 & 1.13 & 0.21 & 1.15 & 0.94 & 0.05 & 0.08 \\
\hline Gel & 68.34 & 15.95 & 4.93 & 0.91 & 1.59 & 1.76 & 2.98 & 0.61 & 0.11 & 0.04 \\
\hline
\end{tabular}

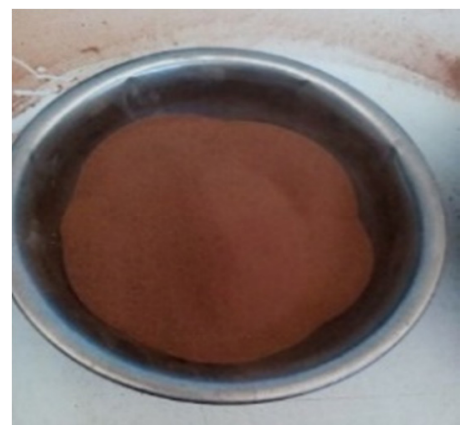

Fig. 1 Calcined kaolinite clay

The calcination was conducted by Kilns and Furnace LTD England Thermo computer TC 60 Type FL350 and its maximum temperature was $1300{ }^{\circ} \mathrm{C}$ found in Kombolcha Polytechnic College. As Fig. 1 shows that the kaolin material was crushed and ground using the machine and sieved using sieve $75 \mu \mathrm{m}$, then inserted into the furnace using a clay plate. Next, the machine was adjusted to Calcination Temperature from room temperature to a $500{ }^{\circ} \mathrm{C}$ rate of $7.9^{\circ} \mathrm{C} / \mathrm{min}$ from $500{ }^{\circ} \mathrm{C}$ to $950{ }^{\circ} \mathrm{C}$ 
rate of $7.9^{\circ} \mathrm{C} / \mathrm{min}$ for the duration of 2 hours and cooled inside the furnace to room temperature at a rate of $5.11^{\circ} \mathrm{C} / \mathrm{min}$. Due to the calcination temperature rate and cooling rate slow, the kaolinite clay has enough time to remove the crystalline bound water of hydration from the entire material in the furnace. The clay is in its most reactive state when the calcination temperature leads to losing of hydroxides and results in a collapsed and disarranged structure as indicated on:

$$
\mathrm{Al}_{2} \mathrm{Si}_{2} \mathrm{O}_{5}(\mathrm{OH})_{4} \rightarrow \mathrm{Al}_{2} \mathrm{Si}_{2} \mathrm{O}_{7}+2 \mathrm{H}_{2} \mathrm{O}
$$

\subsection{Maize stalk celluolse fiber extraction}

The maize stalk fiber was selected due to the abundance, accessibility, mechanical property, and low cost. The maize stalk was collected from a research plantation area at Ethiopia National Agricultural Research Institute Kulumsa center. Its main chemical constitutes are $30 \%-40 \%$ cellulose, $7 \%-21 \%$ lignin, and $28 \%$ hemicellulose. The water retting natural fiber extraction process is used in the research to gain fibers of the greater uniformity and higher quality, the duration of the retting process was 14 days. The maize stalks were harvested on local variety April 12 $2^{\text {th }}, 2017$, and air-dried for 15 days, then was cut in the internodes as indicated in Fig. 2. Each node was split into two pieces and immersed in the solution of $2.5 \mathrm{~g} / 10 \mathrm{~L}$ volume together with its husk as shown in Fig. 3. After 14 days, the lignin was dissolved and cellulose fiber was easily separated from the hemicellulose by hand, then was washed by water several times. The leafy outer shell covering of an ear of maize is referred to as corn husk.

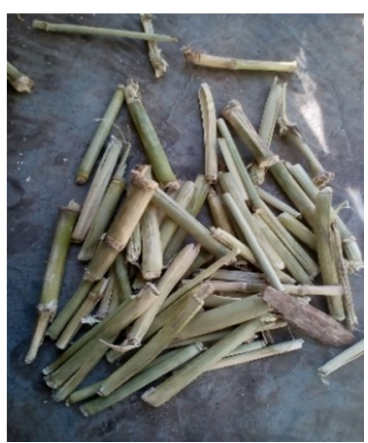

Fig. 2 Raw Maize stalk cut in to the internodes

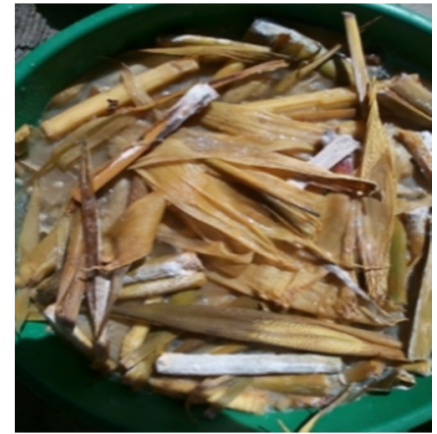

Fig. 3 Maize stalk and husk in retting process

The alkalization is a common preprocessing technique used on natural fiber to remove hemicelluloses, fats, and waxes that may reduce the interfacial strength when processed into the composite form. Therefore, the extracted cellulose fiber was treated by $98 \%$ purity sodium hydroxide for 30 minutes as shown in Fig. 4.

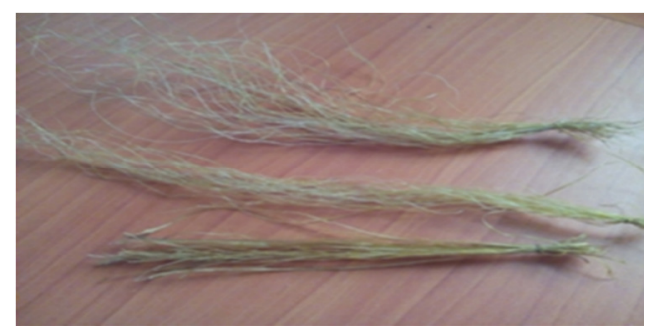

Fig. 4 Extracted sodium hydroxide treated fiber

\subsection{Fiber tensile strength test}

Single maize stalk cellulose fiber tensile strength test was conducted in the research laboratory of Ethiopia Textile, Garment, and Fashion Institute. Fiber tensile strength test of 10 sodium hydroxide treated single maize stalk cellulose fiber conducted using fiber strength test machine. $10 \mathrm{~N}$ load cells, standard gauge length $25 \mathrm{~mm}$, and speed $100 \mathrm{~mm} / \mathrm{min}$ was used for the tensile test of a single fiber with AST MD 3822. Measured average breaking force $2.49 \mathrm{~N}$ and average breaking Elongation of $2.21 \%$ were determined. 


\subsection{Fiber cross section}

A fiber cross-section of single maize stalk cellulose fiber was measured by a biological microscope at the Ethiopia Institute of Agricultural Research Kulumsa Agricultural Research Center laboratory. Sodium hydroxide treated fiber shows a clear surface with no impurities the natural substances on the fiber surface contribute to ineffective fiber-matrix bonding and poor surface wet-out.

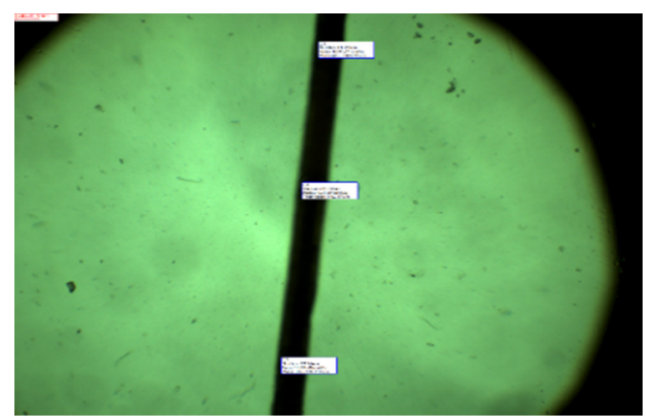

Fig. 5 Fiber cross section imagecaptured by Biological Microscope

Image of sodium hydroxide treated maize stalk fiber of 41 samples were captured by biological microscope and its cross-section measured randomly at the top, middle, and the bottom section from the image by TS view software as shown in Fig. 5. The measured average diameter were $44 \mu \mathrm{m}$, this is in good agreement with recent results from a study of jute fiber diameter by (Virk) who suggested the use of a fiber area correction factor of 1.42 in the measurement of fiber modulus and strength to account the overestimation of the fiber cross-section area by the diameter method [21]. Fig. 6 shows maize stalk single cellulose fiber cross-sectional diameter ranges between $25 \mu \mathrm{m}$ to $60 \mu \mathrm{m}$ and an average of $44 \mu \mathrm{m}$. However, $1.42 \mathrm{cross}$ sectional area correction factors considered during calculation based on the previous researcher.

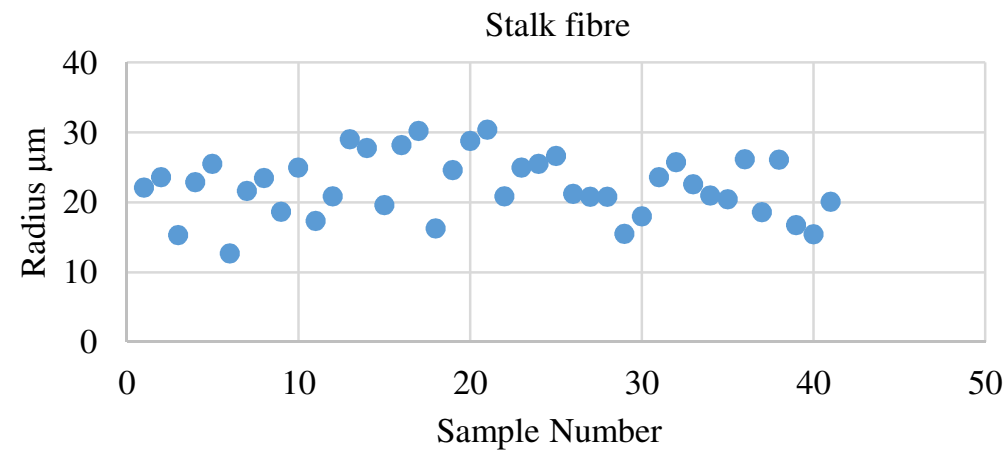

Fig. 6 Maize Stalk fiber cross section

\subsection{Tensile strength result of maize stalk single fiber}

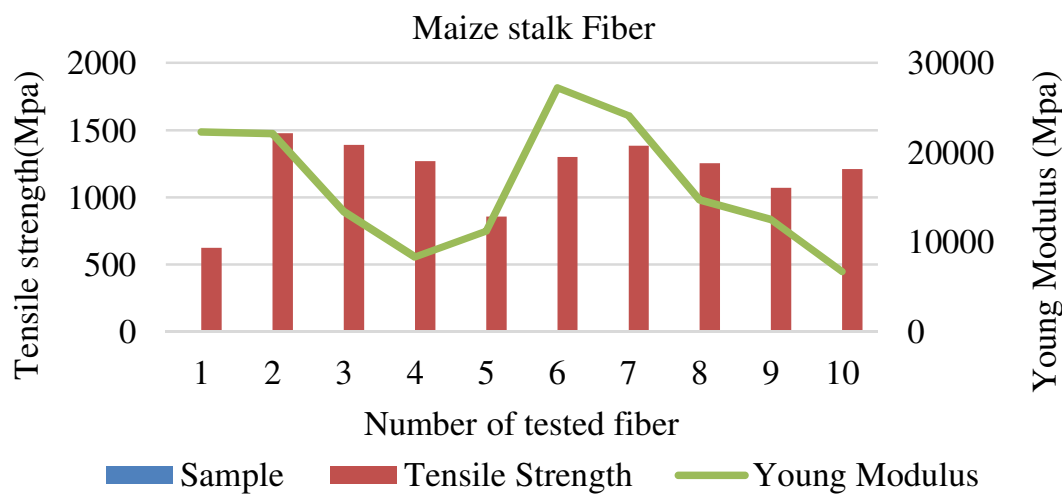

Fig. 7 Tensile strength and Young modulus of single Maize stalk cellulose fiber treated by sodium hydroxide purity $98 \%$ for 30 minutes 
Breaking force and elongation result of ten different samples and cross-section diameter of fiber $44 \mu \mathrm{m}$, gauge length 25 $\mathrm{mm}$ were taken to determine the tensile strength and young modulus as shown in Fig. 7 which the result achieved was 1184 Mpa and 16 Gpa respectively.

The research finding of N. Reddy et al. specifically on breaking elongation and young modulus were comparable to the result achieved [22]. Since the maize stalk abundantly available, biodegradable, and cheap, its sodium hydroxide chemically treated fiber has good mechanical properties possible to use as natural fiber reinforcement.

\section{Geopolymer Composite Processing}

\subsection{Binding agent}

Polymerization is formed by mixing of sodium silicate and sodium hydroxide solution to form $12 \mathrm{M}$ sodium hydroxide solution, the Sodium hydroxide flakes of 489 grams dissolve in deionized water to require the concentration. During the formation of concentration, it liberated a large amount of heat to form polymerization. The mixed sodium silicate and $12 \mathrm{M}$ sodium hydroxide solutions are allowed to keep at room temperature for a minimum of 24 hours and this mixed solution acts as a binding agent as shown in Fig. 8.

Maize stalk fibers were chopped into $5 \mathrm{~mm}$ size and soaked into the sodium hydroxide solution purity $98 \%$ for 30 minutes for the chemical treatment. After 30 minutes, the treated single maize stalk cellulose fiber was washed repeatedly and allowed to dry as shown in Fig. 9.

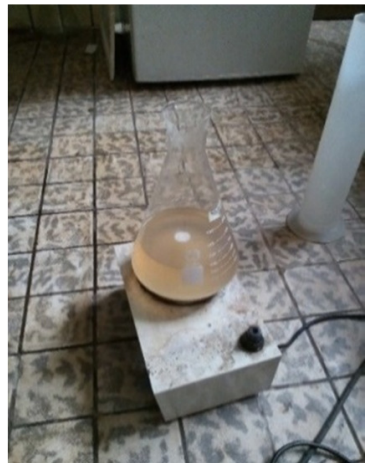

Fig. 8 Bindig agent

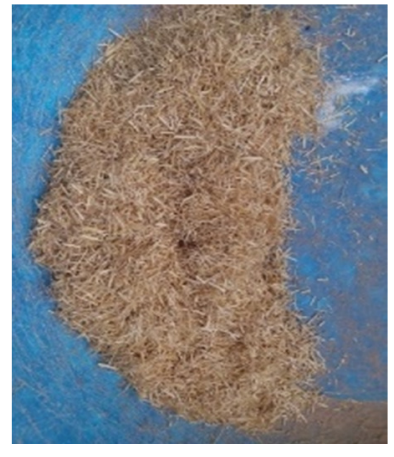

Fig. 9 Chopped treated fiber

\subsection{Mixing, casting and curing}

The maize stalk cellulose fiber-reinforced geopolymer composites were intended to replace conventional cements and concretes, using low carbon emission and producing sustainable green materials. Geopolymer was prepared at the construction material Laboratory, sieved calcined kaolinite clay $(75 \mu \mathrm{m})$, and the single cellulose maize stalk, chopped $5 \mathrm{~mm}$ fiber length $(1$ weight\%). First, dry mixed in a high shear mixer for homogeneous and uniform distribution and sodium water glass was slowly added to the precursor and mixed until complete integration occurred. The geopolymer composite slurry was poured into a high strength plastic mold attached to a vibration table for a more uniform distribution of maize stalk cellulose fiber and fewer voids formation. The filled mold was wrapped in a plastic wrap to prevent water loss during setting and curing. Next, cured for 3 hours in a $50{ }^{\circ} \mathrm{C}$ oven. Then, after 3 days, the geopolymer composite specimen was demolded and set to dry at room temperature for 28 days.

\subsection{Geopolymer composite compression strength}

Universal compression /flexural tester was used to measure the compression strength of the samples. The compression strength test was performed following AST M C1424-10. The compression strength is a measure of the structure's resistance 
or ability to withstand the compression stress. Fig. 10 shows a cylindrical specimen with $25 \mathrm{~mm}$ diameter and $50 \mathrm{~mm}$ height and were tested in accordance with AST M C1424-10. A test was carried out on a universal testing machine with $300 \mathrm{KN}$ load cells at the Addis Ababa Institute of Technology construction material testing laboratory. Three replicated treatments were prepared for the test, samples were subjected to gradual load with the rate of $0.28340 \mathrm{Mpa} / \mathrm{s}$ then the maximum load were recorded at failure. Three replicates were tested for each treatment, the mean ultimate load was taken as the compression strength. The resulting volumetric weight of each treatment was taken as the average of the three cylindrical samples from each mix design and the dimensions of each sample were measured using a caliper and weighed subsequently.

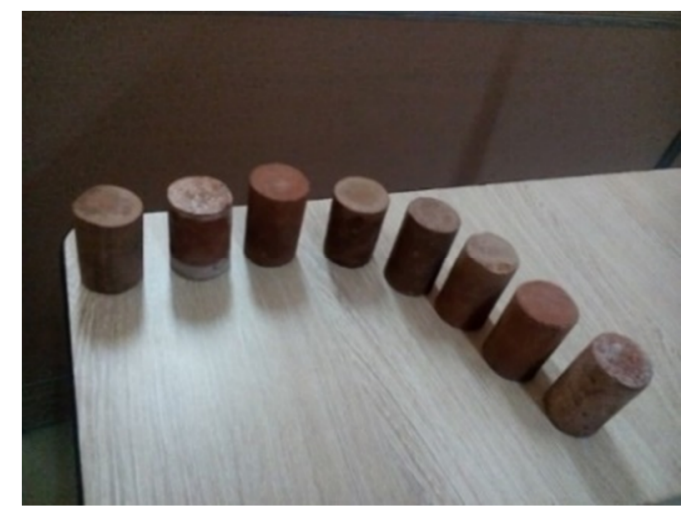

Fig. 10 Cylinderical specimen $25 \mathrm{~mm}$ diameter and height $50 \mathrm{~mm}$

Table 2 shows that the curing method has an effect on the compression strength with the same weight percent of fiber 0.1 weight $\%$ oven-cured sample has more compression strength than the ambient cured sample. The result of 1 weight $\%$ maize stalk fiber geopolymer $27 \mathrm{Mpa}$ comparable to the research finding K. Korniejenko et al. geopolymer composite with 1 weight\% cotton fiber reinforcement which was $28 \mathrm{Mpa}$ [23].

Table 2 Compressionstrength result

\begin{tabular}{|c|c|c|c|c|c|}
\hline $\begin{array}{c}\text { Fber } \\
\text { loading(gram) }\end{array}$ & Force (KN) & Area $\left(\mathrm{mm}^{2}\right)$ & Compression strength (M pa) & Curing method & Density g/cm ${ }^{3}$ \\
\hline 0 & 4.79 & 314 & 15.27 & ambient & 2.453 \\
\hline $0.1 \mathrm{wt} \%$ & 7.5 & 314 & 23.77 & Oven cured & - \\
\hline $0.1 \mathrm{wt} \%$ & 5.58 & 314 & 17.78 & ambient & 2.46 \\
\hline $0.2 \mathrm{wt} \%$ & 9.37 & 490 & 19.09 & ambient & 2.64 \\
\hline $0.6 \mathrm{wt} \%$ & 10.66 & 490 & 21.73 & ambient & 2.44 \\
\hline $1 \mathrm{wt} \%$ & 13.41 & 490 & 27.32 & ambient & 2.32 \\
\hline
\end{tabular}

\section{Result and Discussion}

An average Breaking force $2.49 \mathrm{~N}$ and average breaking elongation $2.21 \%$ result of 10 different maize stalk cellulose fiber samples, and average cross-section diameter of the fiber $44 \mu \mathrm{m}$, gauge length $25 \mathrm{~mm}$ were taken to determine the tensile strength. Young modulus average result was $1184 \mathrm{Mpa}$ and $16 \mathrm{Gpa}$ respectively. Breaking elongation $2.21 \%$ and young modulus 16 Gpa results are comparable to the research finding of $\mathrm{N}$. Reddy et al [22]. The maize stalk single fiber tensile strength test results are in the range of the tensile strength of flax fiber and its young modulus result in the range of young modulus of Abaca and Sisal fiber [24].

Table 2 shows the geopolymer composite compression strength average values of 25-50 mm tested specimens for 28 days curing time. Compared to pure geopolymer, there was an increment of $10 \%$ in compression strength of the composite made from $1 \%$ sodium hydroxide treated single maize stalk cellulose fibers. Additionally, it revealed the increment of $6 \%$ in compression strength of the composite made from $0.1 \%$ sodium hydroxide treated single maize stalk cellulose fiber, oven-cured at $60{ }^{\circ} \mathrm{C}$ for 4 hours and left to dry for 28 days at the ambient condition when compared to cured by the ambient 
condition. The average of the compression strengths of three specimens was taken as the measured value for each run geopolymer. The measured samples indicate compression strength $16 \mathrm{Mpa}$ to $27 \mathrm{Mpa}$ from pure geopolymer up to 1 weight $\%$ fiber loading as shown in Fig. 11. Compression strength requirements are at least $17 \mathrm{Mpa}$ and $28 \mathrm{Mpa}$ for residential and commercial concrete respectively [25]. The density of pure geopolymer samples $2.45 \mathrm{~g} / \mathrm{cm}^{3}$ and $1 \mathrm{weight} \%$ fiber loading 2.32 $\mathrm{g} / \mathrm{cm}^{3}$ were determined.

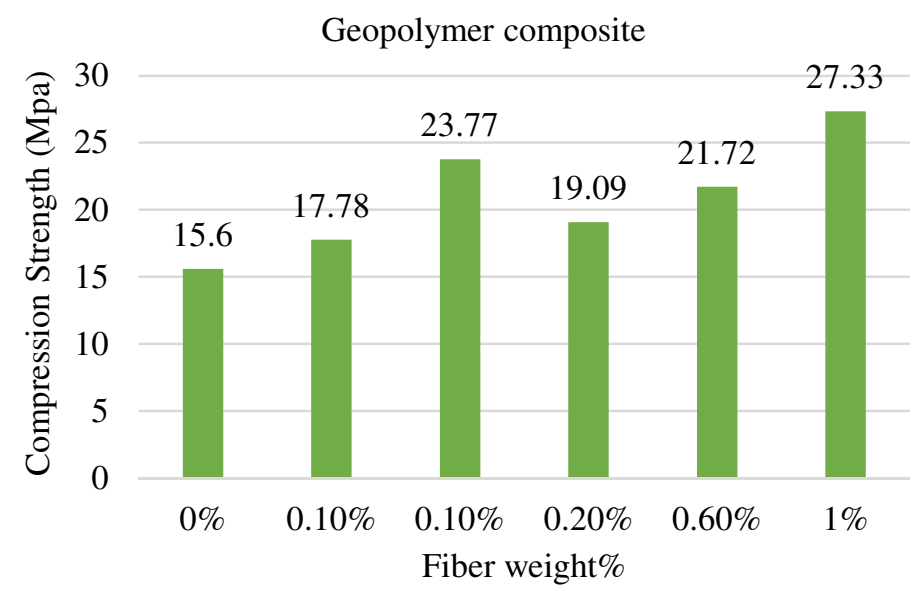

Fig. 11 Compression strength of geopolymer reinforced by maize stalk fiber

\section{Conclusions}

The clay mineral is abundantly available in Ethiopia at a different location and the sample clay material was taken from Burayu white clay, Chefe red clay soil, and gel. Their chemical composition analysis test was conducted on the Ethiopian Geological Laboratory center. According to the results, chefe red clay soil has good $\mathrm{SiO}_{2}$ and $\mathrm{Al}_{2} \mathrm{O}_{3}$ content than other samples. The kaolinite clay was calcined in the laboratory from room temperature to a $500{ }^{\circ} \mathrm{C}$ rate of $7.9^{\circ} \mathrm{C} / \mathrm{min}$, from $500{ }^{\circ} \mathrm{C}$ to $950{ }^{\circ} \mathrm{C}$ rate of $7.9^{\circ} \mathrm{C} / \mathrm{min}$ for two hours to obtain the precursor material. The chemical treatment is done on the extracted the maize stalk and husk fiber using the sodium hydroxide purity $98 \%$ for 30 minutes, then the tensile strength testing carried out based on AST M D 3822 standard. Tensile strength 1184 Mpa and young modulus $16 \mathrm{Gpa}$ achieved for single maize stalk cellulose fiber.

The average of the compression strengths of three specimens was taken as the measured value for each run geopolymer sample. The masured compression strength of the Pure geopolymer was $16 \mathrm{Mpa}$ and for 1 weight \% fiber loading $27 \mathrm{Mpa}$, which approach with $28 \mathrm{Mpa}$ compression strength of geopolymer from fly ash 1 weight $\%$ cotton fiber loading that cured for 28 days. Since the maize stalk cellulose fiber density is significantly lower than that of Calcined kaolinite clay, it is reasonable for the geopolymer composite density to decrease with maize stalk cellulose fiber loading. Maize stalk cellulose fiber reinforced calcined kaolinite clay geopolymer composite can be used for the finishing material for interior wall application.

\section{Conflicts of Interest}

The authors declare no conflict of interest.

\section{References}

[1] A. K. Mohanty, M. Misra, and L. T. Drzal, Natural fibers,biopolymers, and biocomposites, 1st ed. New York: CRC Press, 2005.

[2] J. A. Youngquist, B. E. English, H. Spelter, and P. Chow, "Agricultural fibers in composition penels," Proceedings of the 27th International Particleboard /Composite Materials Symposium, 1993, pp. 133-152. 
[3] D. O. Ekhuemelo, "Assessment of fiber characteristics and suitability of maize husk and stalk for pulp and paper production," Journal of Research in Forestry, Wildlife and Environmental, vol. 5, no. 1, pp. 41-49, March 2013.

[4] L. Zhang, Z. Yang, and H. Guo, “Tensile Properties of Maize stalk rind,” Bioresource, vol. 11, no. 3, pp. 6151-6161, May 2016.

[5] P. Baranitharan and G. Mahesh, "Alkali treated maize fiber reinforced with epoxy polymer matrix composites," International Journal of Innovative Science and Modern Engineering, vol. 2, no. 5, pp. 1-7, April 2014.

[6] N. Reddy and Y. Yang, "Biofibers from agricultural byproducts for industrial applications," Trends in Biotechnology, vol. 23, no. 1, pp. 22-27, January 2005.

[7] G. Henrikson, D. E. Akin, R. T. Hanlin, C. Rodriguez, D. D. Archibald, L. L. Rigsby, and K. L. Eriksson, "Identification and retting efficiencies of fungi isolated from dew-retted flax in the United states and Europe," Applied and Environmental Micropbiology, vol. 63, no. 10, pp. 3950-3956, October 1997.

[8] I. Doraiswamy and P. Chellamani, Pineapple leaf fibers, 1st ed. North Carolina: North Carolina State University, 1993.

[9] M. Dauda, M. Yoshiba, K. Miura, and S. Takahashi, "Processing and mechanical properties of long maize fibers reinforced polypropylene composites," Transactions of the Materials Research Society of Japan, vol. 26, no. 4, pp. 1083-1090, January 2001.

[10] S. Bavan and M. K. G. Channabasappa, "Examination of tensile strength and FTIR features of maize fibers reinforced polymer composite," International Journal on Recent Trends in Engineering And Technology, vol. 5, no. 4, pp. 27-30, March 2011.

[11] H. H. Murray, “Overview clay mineral application,” Applied Clay Science, vol. 5, no. 5-6, pp. 379-395, March 1991.

[12] H. H. Murray, "Traditional and new applications for kaolin,smectite and palygorskite:a general over view," Applied Clay Science, vol. 17, no. 5-6, pp. 207-221, March 2000.

[13] G. Bedassa, "Characterization of the genesis of belessa kaolin occurrences, hosaina area." Master thesis, Deptment Resource Geology, Addis Ababa University, Addis Ababa, June 2017.

[14] B. B. Sabir, S. Wild, and J. Bai, "Metakaolin and calcined clays as pozzolans for concrete," Cement and Concrete Composites, vol. 23, no. 6, pp. 441-454, December 2001.

[15] A. Nmir, N. Hamdi, O. Yazoghli-Marzoul, M. Duc, and E. Srasra, "Synthesis and characterization of kaolinite based geopolymer: Alkaline activation effect on calcined kaolinitic clay at different temperature," Journal of Materials and Environmental Science, vol. 8, no. 2, pp. 676-690, 2017.

[16] J. Davidovits, "Properties of geopolymer cement," Proceedings First International Conference on Alkaline Cements and Concretes, 1994, pp. 131-149.

[17] S. N. Janne Paulin and B. P. Michael Angelo, "Development of abaca fiber reinforced foamed fly ash geopolymer," MATEC Web of Conferences, vol. 156, pp. 1-8, 2018.

[18] L. C. Silva, R. A. dos Reis Ferreira, et al., "Optimization of metakaolin based geopolymer composite using sisal fibers,response surface methodology and canonical analysis," International Journal of Advanced Engineering Research Science(IJAERS), vol. 6, no. 4, pp. 32-44, April 2019.

[19] M. Ravi, "Biocomposite panels from recycled wood chips for sustainable building applications," Master thesis, Deptartment Civil Engineering, University Of British Columbia, Vancouver, August 2019.

[20] D. Wattanasiriwech, T. Munmueangkham, and S. Wattanasiriwech, "Impact strength and physical properties of geopolymer composites reinforced with bagasse cellulose fibers," 2018 World Congress on Advances in Civil, Environmental \& Materials Research (ACEM18), August 2018, pp. 1-7.

[21] A. S. Virk, "Numerical models for natural fiber composites with stochastic properties," Ph.D. dessertation, School of Marine Science and Engineering, University of Plymouth, Plymouth, 2010.

[22] N. Reddy and Y. Yang, Innovative biofibers from renewable resources, 1st ed. Verlag Berlin Heidelberg: Springer, 2015.

[23] K. Korniejenko, E. Fraczek, E. Pytlak, and M. Adamski, "Mechanical properties of geopolymer composites reinforced with natural fibers," International Conference on Ecology and New Building Material Products, 2016, pp. 388-393.

[24] M. C. Symington, W. M. Banks, and O. D. West, "Tensile testing of cellulose based natural fibers for structural composite applications," Journal of Composite Material, vol. 43, no. 9, pp. 1083-1108, 2009.

[25] National ready mixed Concrete association(NRMCA) "Concrete in practice" http://welschreadymix.com/wpcontent/uploads/2016/04/CIP35- Testing_Compresive_Strength_of_Concrete.pdf, June 2017.

Copyright $\subseteq$ by the authors. Licensee TAETI, Taiwan. This article is an open access article distributed under the terms and conditions of the Creative Commons Attribution (CC BY-NC) license

(https://creativecommons.org/licenses/by-nc/4.0/). 